\title{
Teología e historia en el Antiguo Testamento
}

\author{
Andrés Ferrada Moreira, Pbro. \\ PONTIFICIA UNIVERSIDAD CATÓLICA DE CHILE \\ FACULTAD DE TEOLOGÍA
}

La afirmación del célebre literato francés Paul Valèry (1871-1945) «Los pueblos felices no escriben historia» pone de manifiesto la razón de la existencia de buena parte de la literatura universal, en especial del género histórico. ¿Por qué los pueblos narran su historia?; o entrando más de lleno en nuestra temática, ¿por qué Israel ha dejado por escrito la génesis de su existencia como nación? Sin duda, porque la subsistencia de Israel como pueblo estuvo seriamente amenazada en aquellas épocas en las que se fraguó la escritura de los textos que narran las gestas de sus orígenes patrios. Pero no es solo por eso, sino también porque en esos trances el pueblo elegido percibió que su subsistencia dependía del concurso de un actor sobrenatural, el Señor, y que su actuación no dejaría de continuar en el presente.

Historia y teología, por tanto, están íntimamente enlazadas en los relatos del Antiguo Testamento. En esta presentación describiremos cómo se enlazan e intentaremos mostrar cómo la Biblia Hebrea, al narrar los orígenes de Israel, persigue principalmente iluminar el presente de sus destinatarios infundiéndoles esperanzas en la actuación salvífica del Señor en las duras condiciones sociopolíticas por las que atraviesan.

En primer lugar, debemos rozar la compleja historia de la composición de los libros y unidades literarias del Antiguo Testamento, cuyo estudio, aun en líneas generales, excede con mucho las posibilidades de esta exposición. Por eso, parece prudente circunscribir nuestra atención a la composición del Pentateuco, que nos servirá para ilustrar la relación 
que existe entre teología e historia en el Antiguo Testamento. Esta delimitación, además, resulta oportuna en atención al contenido mismo del Pentateuco, es decir, la Ley (Torá). Ella constituye el fundamento institucional, sociopolítico y religioso del pueblo elegido y, por lo mismo, es la unidad literaria fundamental del Antiguo Testamento.

¿Por qué fueron compuestos los cinco primeros libros de la Biblia y coordinados en una unidad literaria?

La respuesta a esta interrogante encuentra una primera iluminación al poner en evidencia la función singular de la Torá en el contexto de todos los libros de la Biblia Hebrea. Exponemos ahora apretadamente cómo E. Zenger la pone de manifiesto desde el punto de vista canónico ${ }^{1}$. Estudia el contenido de los textos que hacen de bisagras entre las tres partes de la Biblia Hebrea, a saber, la Ley, los Profetas y los otros Escritos (Torá, Nebiim y Ketubim): Dt 34, 10-12; Jos 1, 1-8; Ml 3, 22-24; Sl 1 y 2 Cr 36, 22-23. Después de un fino análisis de todos estos pasajes, el exégeta bávaro concluye que en todos ellos, de una u otra manera, queda de manifiesto el carácter único y la autoridad sin comparación del Pentateuco dentro del Antiguo Testamento ${ }^{2}$. La Ley contiene y transmite normativamente la voluntad del Señor, lo que Él prescribe como indispensable para la existencia del pueblo, tanto a nivel personal, como comunitario. La autoridad de la Torá trae aparejada, también, la superioridad de Moisés, mediador de la Ley, sobre todos los demás profetas o portadores de la revelación divina ${ }^{3}$.

1 Cf. E. Zenger, Einleitung in das Alte Testament (Sttutgart 1995) 24-26. A. Bentué, Dios $y$ dioses (Santiago 2004) 141-160 explica el judaísmo, aunque distingue entre judaísmo bíblico y judaísmo rabínico, pienso que con una finalidad escolástica, subtitula sugestivamente «Fidelidad a la Torah» (40-56) el acápite donde expone la génesis del rabinismo hasta nuestros días, subrayando la continuidad en el interés por la fidelidad a la Torá entre los rabinos de la época intertestamentaria y los escribas que pusieron por escrito las principales tradiciones hebreas antiguas. Es ese mismo el espíritu, claro está con acentuaciones diversas, el que le dio la forma canónica a la Biblia Hebrea.

2 Seguimos en particular la recepción de la teoría en J.-L. SKA, Introducción a la lectura del Pentateuco. Claves para la interpretación de los cinco primeros libros de la Biblia (Estella 2001) 23-31.

3 Por otra parte, la función canónica de la Torá es corroborada en el Nuevo Testamento. En efecto, en él se hacen continuas referencias a la Ley que Jesús actualiza con su enseñanza (Mt 5, 17-19), gestos (Mc 14, 22-25) y sobre todo con su pasión y muerte (Jn 19, 30). Por lo demás, es claro que en los escritos neotestamentarios se sigue la disposición hebrea de la Biblia, así lo demuestra el uso del díptico «La Ley y los Profetas» (cf. Mt 5, 17; 7, 12; 22, 40; Lc 16, 16; Jn 1, 45; Hch 13, 15; 24, 14; 28, 23; Rm 3, 21) y del menos común tríptico «La Ley, los Profetas y los Salmos» (Lc 24, 44). 
En consecuencia, los Nebiim y los Ketubim encuentran su sentido en relación con la Torá4: La profecía se entiende en el hoy, en el presente, como actualización de la Ley, siempre en relación con un ayer cuando la Ley fue promulgada por el Señor en el Sinaí y dada al pueblo por la mediación de Moisés 5 . Otro tanto sucede con los «Otros escritos», cuya interpretación remite a la meditación sapiencial de la Torá, actitud que caracteriza al sabio de Israel, es decir, aquel que sabe conducir su vida conforme al querer del Señor (cf. Sl 1) ${ }^{6}$.

Volvamos ahora sobre por qué fueron compuestos los cinco primeros libros de la Biblia y coordinados en la unidad literaria inicial de ella. Ya adelantamos que lo que estaba en juego en la escritura de la historia de los orígenes de Israel era su subsistencia como pueblo. Desde el punto de vista histórico esta afirmación requiere rastrear los momentos coyunturales de la existencia de Israel donde, de hecho, su destino nacional estuvo desafiado por la desaparición. Para esta indagación requerimos unas herramientas metodológicas que solo la ciencia histórica puede aportar, especialmente el detenido análisis histórico-crítico de las fuentes no exclusivamente bíblicas, sino también extrabíblicas, y el contraste de los resultados obtenidos con los datos aportados por la arqueología y otras ciencias humanas.

Por de pronto, es necesario comenzar distinguiendo entre el mundo narrado por los textos bíblicos y el mundo de los destinatarios de estos relatos ${ }^{7}$. De hecho, una de las dificultades mayores que enfrentan los lec-

Además, es particularmente sugerente que estas expresiones aparezcan casi siempre en boca de Jesús.

4 Cf. la recepción de la teoría en J.-L. SKA, Introducción, 23-31.

5 Son muchos los textos proféticos donde claramente la profecía se revela como la actualización de la Ley. Cf., p. ej., 1Re 2, 1-4; 2Re 21, 8-12; Am 2, 4-8; Is 42, 20-25; Jr 6, 19-23; Ez 22, 26-31.

6 Numerosos pasajes de los «Otros escritos» remarcan el valor que tiene la Torá como orientadora indispensable de la conducta humana. Cf., p. ej., Dn 9, 9-13; Ne 1, 7-11; Ne 10, 28-30; Sl 40, 7-11; Sl 89, 28-33; Pr 28, 4-9.

7 S.D. BEESON, «Historiography Ancient and Modern: Fact and Fiction» en G.J. BrooKe - T. RÖMER, Ancient and Modern Scriptural Historiography. L'Historiographie biblique ancienne et modern (Leuven 2007) 3-12, 9: «Texts tell us most about their time of autorship, rather than of the time they describe». Esto porque la historiografía es siempre subjetiva ya que es el relato continuo que un autor hace hilvanando una serie de hechos históricos en una concatenación. En ella hay siempre algo de ficción, pues involucra un proceso de selección de datos según sean los intereses y puntos de vista de aquel 
tores del Pentateuco en la actualidad es asimilar que los textos narrativos de la Ley no constituyen un libro historiográfico de los orígenes de Israel, sino que son históricos en otro sentido, en clave histórico-salvífica ${ }^{8}$. Si bien hoy se acepta este dato fácilmente para relatos como la creación y el pecado original (Gn 1-3), cuesta que se imponga para el resto, sobre todo para narraciones donde los rasgos históricos son muy marcados: los ciclos de los patriarcas, la esclavitud y liberación de Egipto, la perícopa del Sinaí y la peregrinación por el desierto.

En efecto, los relatos del Pentateuco no persiguen en primer lugar iluminar la historiografía de Israel, sino brindar los elementos constitutivos de su existencia como pueblo del Señor y, por lo mismo, transmitir el mensaje de salvación que esta realidad significa. Este es el sentido histórico-salvífico al que nos estamos refiriendo que, sin duda, es una lectura teológica de los acontecimientos narrados. Por eso, para captar su significado, el lector debe diferenciar entre la historia narrada y la situación vital a la que esta historia pretende dar respuesta. Esta situación es la que más importa al intérprete y al historiador, pues explica el porqué fue escrito un determinado texto, explica su sentido histórico.

No obstante sería exagerado eliminar de un plumazo el estudio historiográfico de no pocos acontecimientos de la historia narrada en el Pentateuco (y en el resto de los libros del Antiguo Testamento). Sin embargo, en ella se contienen, en realidad, no muchos datos comprobados por la ciencia histórica. Algunos autores llaman a esos datos fondo histórico de una narración. Los datos mejor fundados van en aumento, eso sí, en la medida que se avanza en el decurso de la historia, precisamente porque aumentan las posibilidades de rastro historiográfico gracias a la existencia de fuentes extrabíblicas que documentan los mismos hechos. Pero se impone cada vez con mayor claridad, que a partir de los datos historiográficamente comprobados presentes en los cinco primos libros de la Biblia no es posible conformar un relato completo y coherente de los orígenes de Israel. Para conseguirlo, es necesario, como decíamos antes, recurrir a datos aportados por el estudio de fuentes extrabíblicas y por las disciplinas

autor. S.D. BEESON, Historiography, 11 concluye: «If all historiography is ideology, then "historians of Israel" ought first to be students of the ideologies it has engendered, before they then proceed to contribute from position of their own ideologies to the array of the ideological fictional readings of the past».

8 Según la visión consagrada en la Constitución dogmática sobre la Divina Revelación, Dei Verbum, del Concilio Vaticano II. 
auxiliares de la ciencia histórica, especialmente de la arqueología. El proceso puede ser calificado como la normalización de la historia de Israel ${ }^{9}$.

No obstante lo anterior, el exégeta (y el historiador) tiene otro camino de investigación histórica en relación al Pentateuco, que le aporta luces imprescindibles para la comprensión de su mensaje. En efecto, como aseverábamos más arriba, la historia narrada en los cinco primeros libros de la Biblia le permite, también al contrastarla con otras fuentes y datos arqueológicos, iluminar, no sin limitaciones e incertezas, el mundo de los destinatarios a los que toda o parte de esa historia sagrada estaba dirigida. Ciertamente, esta iluminación es historiografía. En el presente ya contamos con varias obras emblemáticas que siguen este camino ${ }^{10}$.

Aunque resulta casi evidente, es necesario advertir también que la historiografía no goza de una objetividad absoluta independiente del sujeto que lee los acontecimientos. Una objetividad así es una pretensión que, en realidad, no se corresponde adecuadamente con la naturaleza misma del discurso histórico, el cual es siempre interpretativo y, por lo mismo, incluye subjetividad e ideología. En efecto, se escribe historia con miras a moldear de alguna manera el presente y siempre desde un determinado punto de vista, el del autor. Afortunadamente, grandes sectores de la ciencia histórica actual son cada vez más conscientes de esta realidad y se va perfilando como un requerimiento metodológico necesario el conocimiento del punto de vista del autor del relato histórico para poder interpretarlo y actualizarlo en el presente del lector ${ }^{11}$.

9 Partimos de la base que la ciencia histórica es capaz de normalizar el estudio de la historia de Israel, usando de las mismas herramientas que se usan para el estudio histórico de cualquier pueblo antiguo. En este tema iluminan bastante los siguientes artículos: el antes citado S.D. BEESON, Historiography, 3-12 y dos artículos que aparecen en el mismo volumen P.R. DAvies, «Another Country? Biblical Texts and the Past» en G. J. Brooke - T. Römer, Ancient and Modern, 13-24 y W. W. KeIth, «The Poetic of the History of Israel: Shaping Palestinian History» en G.J. Brooke - T. Römer, Ancient and Modern, 26-45.

10 Dos ejemplos: I. Finkelstein - N.A. Silberman, The Bible Unearthed. Archaelogy's New Vision of Ancient Israel and the Origin of Its Sacred Texts (New York 2001) = La Biblia desenterrada. Una nueva visión arqueológica del antiguo Israel y de los origenes de sus textos sagrados (Madrid 2005) y M. Liverani, Oltre la Bibbia. Storia antica di Israele (Roma - Bari 2003) = Más allá de la Biblia. Historia antigua de Israel (Barcelona 2005).

11 P. R. DAviEs, Another Country? plantea que la ya clásica distinción entre historiografía e historia (story), propia de la ciencia histórica moderna, debe ser relativizada, pues no es exacto que, pese a la pasión por los hechos (facts), un relato historiográfico actual goce de un alto nivel de historicidad, en comparación con las historias narradas 
Un ejemplo analógico iluminará lo que estamos tratando de decir. Si consultamos distintos libros para estudiar la Independencia de Chile, los acontecimientos serán narrados de forma diferente según sean tanto los diversos puntos de vista de los autores, como las necesidades de los destinatarios a los que las diferentes obras históricas están dirigidas. Así, por ejemplo, un libro de 1830 contará los episodios con tono de epopeya, los patriotas serán héroes y los realistas, traidores. Si el libro proviene de 1910, el primer centenario patrio, los acontecimientos continuarán siendo sustancialmente los mismos, pero ahora se dará más importancia a la trascendencia republicana de los mismos, pues los destinatarios perciben los hechos de 1810 como el irreversible inicio de la república chilena. Si el libro fuera actual, en el año del bicentenario, la presentación de los mismos hechos históricos de la Independencia muy posiblemente estaría mediada por los intereses de los destinatarios contemporáneos. Tal vez, se matizarían las diferencias entre los bandos enfrentados y se haría referencia con mayor precisión a los factores externos que influyeron en el desencadenamiento de los acontecimientos.

Algo similar pasa al estudiar los relatos bíblicos; ellos no solo hablan de un mundo narrado, que en el caso de las narraciones del Pentateuco es solo arduamente rastreable para la ciencia histórica, sino también y principalmente nos ponen en contacto con el mundo de sus destinatarios y, en especial, con sus necesidades vitales, a las que un autor concreto intentaba dar respuesta ${ }^{12}$.

en el Antiguo Testamento. Hay varias maneras de contar el pasado según sean los intereses del autor o grupo que él representa.

12 Podría objetarse quizás que en la literatura antigua, con mayor razón en las obras de carácter popular, el autor es generalmente anónimo y, además, los textos recogen tradiciones orales, que hunden sus raíces en una transmisión inmemorial. Por lo tanto, sería imposible conocer al escritor de un texto antiguo y, con mayor razón, descubrir su intención al escribirlo. Con todo, durante el siglo XX, los estudios de la tradición oral y del folclore han demostrado que, del mero hecho de la presencia de una serie de motivos tradicionales en un texto antiguo, no puede deducirse que tales motivos sean necesariamente el resultado de la puesta por escrito de tradiciones orales cuidadosamente memorizadas. Al contrario, una tradición puede sufrir toda clase de modificaciones, tanto de forma como de contenido. En cualquier etapa de su transmisión una tradición puede incorporar, p. ej., diversos patrones folclóricos. La explicación de este fenómeno es sencilla: la transmisión de una tradición es siempre creativa, es decir, reinterpreta, reactualiza su mensaje según las nuevas necesidades de la comunidad. Para la aplicación de estas investigaciones a los estudios bíblicos, so- 
Veamos un ejemplo concreto del Pentateuco: la fina narración del matrimonio de Isaac con Rebeca del capítulo 24 del libro del Génesis. En el relato, hay elementos tradicionales propios de la catequesis y/o predicación popular. Destaca el uso de la escena típica del encuentro junto al pozo ${ }^{13}$, desarrollada también en otras narraciones del Pentateuco: el matrimonio de Jacob con Raquel en Gn 29 y el matrimonio de Moisés con Sífora en Ex $2^{14}$. En todas ellas se relata el encuentro junto a un pozo del protagonista de la historia, joven soltero y que viene de lejos (o su representante), con una o más jóvenes casaderas. Media el abrevar ya de la cabalgadura y/o de la tropilla del recién llegado, ya del ganado que conduce la mujer al pozo, ya de ambos. Aunque cada trama tiene un tratamiento con circunstancias diferentes, todas terminan con el matrimonio del protagonista con la joven (o una ellas), que abre paso a la narración del nacimiento de los hijos de los recién casados. Así como Gn 24 narra la misión del viejo siervo de Abraham, quien se encuentra junto al pozo con la hija de Betuel, pariente de su amo, y termina con el matrimonio de Isaac y Rebeca, así también Gn 29 narra el final del viaje de Jacob a Padam-aram, donde junto al pozo encuentra a Raquel, su pariente, con quien después de muchas peripecias vuelve a Canaán junto al hijo de ambos, José ${ }^{15}$. Así también, Moisés, fugitivo de Egipto, se topa junto al pozo con las siete hijas de Reuel, sacerdote de Madián, y al final contrae matrimonio con

bre todo veterotestamentarios, resulta muy iluminador P.G. KIRKPATRICK, «The Old Testament and Folklore Study», JSOTSS 62 (Sheffield 1986).

13 Cf. R. Alter. «Biblical Type-Scenes and the Uses of Conventio» en IBíD., The Art of Biblical Narrative (New York 1981) 47-62; J.G. Williams, «The Beautiful and the Barren: Conventions in Biblical Type-Scenes», JSOT 17 (1980) 107-119, especialmente 109; IBíD., Women Recounted: Narrative Thinking and the God of Israel (Sheffield 1982) 45-46. También respecto de Ex 2, 15-22 en J.-L. SKA, «La scena típica dell’incontro presso il pozzo» en IBíD., Esodo 1-4. I primi Quattro capitol dell'Esodo nel loro contesto. Ad usum privatum alumnorum PIB (Roma 1997-1998) 82-84; respecto de Jn 4 (Jesús y la samaritana) en J.-L. SKA, «Gesù e la samaritana (Gv 4). Utilità dell'Antico Testamento» en IBíD., La strada e la casa. Itinerari biblici (Bologna 2001) 195-208.

14 Cf. Jn 4, 1-2 y también 1Sam 9, 11; 1Re 17, 10.

15 La narración tiene una trama bastante compleja. El matrimonio de Jacob y Raquel se entreteje con el enlace del patriarca con Lía, hermana mayor de Raquel, producto del engaño de Labán, padre de ambas chicas, y el nacimiento de los numerosos hijos de Jacob con Lía y con las esclavas Zilpá, perteneciente a Lía, y Bilhá, propiedad de Raquel (Gn 29, 1-30, 24). 
una de ellas, Sífora, y engendra de ella a Guersón, su hijo primogénito (Ex $2,15 b-22)^{16}$.

Volvamos sobre el matrimonio de Isaac con Rebeca. El relato subraya el origen en el mismo linaje de todos los antepasados de los israelitas, tanto por línea paterna, como materna. De hecho, Abraham encarga a su mayordomo ir a la Alta Mesopotamia para encontrar allí una esposa para su hijo Isaac entre las chicas de su parentela (Gn 24, 3.37). Por contraste, le prohíbe tomar mujer para Isaac de entre las mujeres cananeas (Gn 24, 4. 38.40$)^{17}$.

Esta observación sugiere que lo que Gn 24 pretende transmitir no es la narración historiográficamente controlable del matrimonio de Isaac y Rebeca - de hecho, no poseemos otras fuentes que permitan tal verificación-, sino la importancia de la ascendencia de los esposos que contraen matrimonio dentro del pueblo de Israel. No se trata de excluir a priori la historicidad del relato, ni denegar tal vez algún fondo histórico al que pueda aludir, pero es evidente que no es posible pasarlo por la criba de los datos aportados por la literatura antigua comparada y por la arqueología en relación con el período histórico antiquísimo al que, según la cronología bíblica, correspondería la narración. En efecto, según la cronología bíblica más común, Gn 24 narraría acontecimientos sucedidos aproximadamente hacia el año 1700 a. C. ${ }^{18}$.

Está fuera de discusión el hecho evidente que Gn 24 fue compuesto en un tiempo muy posterior al período histórico en el que se ambienta. Esto, claro está, debe decirse de todos los acontecimientos narrados en la Biblia entre Gn y Jue, pues ellos sucedieron con anterioridad al siglo X, los tiempos de la monarquía davídico-salomónica. En efecto, de antes de ese tiempo remoto, apenas habrá algún autor que se atreva a aventurar la existencia de escritura literaria en el pueblo de Israel. Las ciencias auxiliares aportan, además, algunos indicios acerca de ciertas inverosimilitudes

16 Para un análisis de Ex 2, 15b-22 cf. J.-L. SKA, «La scena típica» 82-84.

17 La prohibición en cuestión también está supuesta en Gn 29, pues en Gn 28, 1-6 Isaac ordena explícitamente a Jacob ir a Mesopotamia en busca de esposa entre las hijas de sus parientes y le prohíbe tomar mujer de entre las cananeas. De hecho, esto último es lo que Isaac y Rebeca reprochaban a Esaú (Gn 27, 46; 28, 6). En Ex 2, en cambio, este elemento es contrastado, pues el protagonista, hebreo de cepa sacerdotal por ambos costados $(\operatorname{Ex} 2,1)$, contrae matrimonio con una extranjera, aunque también de raigambre sacerdotal (cf. Ex 18, 10-12).

18 Así como Gn 29 se refiere a hechos datables un siglo más tarde y Ex 2, hacia el 1200 a. C. 
históricas de lo narrado en Gn 24. Así, por ejemplo, hay evidencia que demuestra que el camello fue domesticado solo al final del segundo milenio a. C. ${ }^{19}$. Por lo tanto, si el acontecimiento narrado en Gn 24 sucedió en la primera mitad del segundo milenio a. C., es altamente improbable que Rebeca y su séquito hayan montado en ese tipo de cabalgadura ${ }^{20}$.

Con todo, para la interpretación del pasaje se requiere precisar mejor el ambiente histórico en el cual ha surgido, pues lo decisivo es poner a la luz las necesidades vitales a las que intentaba dar respuesta. La exégesis no tiene otra vía para hacerlo sino el fino estudio tanto de la forma como del contenido del relato. De hecho, han emprendido esta tarea no pocos exégetas en los dos últimos siglos ${ }^{21}$.

Hay claros y suficientes indicios para sostener que la forma lingüística de Gn 24 es tardía. Seguimos el luminoso análisis del texto del gran biblista israelí de origen italiano Alexander Rofé2 ${ }^{22}$, aunque se debe advertir que

19 I. Finkelstein - N.A. Silberman, The Bible Unearthed, 37. Aunque corrientes conservadoras tratan de contrarrestar este argumento, cf. PersonAl DE A.P. - E. LyONS, «Camellos y redacción del Génesis» en http://apologeticspress.org/espanol/articulos/2938, con bibliografía.

20 La palabra camello aparece $17 x$ en Gn 24. Es significativo que aparezca 2x en Gn $31,17.34$, donde se afirma que Jacob monta a sus mujeres en camellos. Esta última narración está directamente relacionado con Gn 29 // Gn 24.

21 Para un buen resumen de la historia de la investigación cf. G.J. WenHAm, Genesis $16-$ 50 (Dallas 1994) 137-140. Los cultores de la hipótesis documental asignaban Gn 24 al yavista. Algunos autores sostenían que era producto principalmente de la fusión de dos recepciones yavistas de la misma tradición (cf. H. GunKEL, Genesis (Atlanta 1997) $241-249=$ Göttingen $^{3}$ 1910). Otros biblistas lo asignaban al yavista y las tensiones que percibían en él las atribuían a inserciones menores o ampliaciones parciales del mismo yavista [es la postura de M. Noth, una excelente síntesis cf. A.F. Campbell - M.A. O'Brien, Sources of the Pentateuch. Texts, Introductions, Annotations (Minneapolis 1993) 105-108]. A medio camino entre las dos posturas aludidas se encuentran algunos autores que sostienen que Gn 24 es yavista pero reciente. Plantean dos posibilidades: o el relato ha sido reelaborado totalmente en época tardía (cf. C. Westermann, Genesis 12-36. A commentary (London 1985) 383-384 = NeukirchenVluyn 1981) o el yavista es un autor derechamente tardío [cf. J. VAN SETERS, Abraham and Tradition (New Haven 1975) por citar una de sus obras más antiguas].

22 Seguimos solo con alguna leve variación y complemento la reflexión de A. RofÉ, «An Inquiry into Betrothal of Rebekah» en Die Hebräische Bibel und ibre zweifache Nachgeschichte (Fs. R. Rendtorff), (Neukirchen-Vluyn 1990) 27-39, condensada en IBíD., «Introduzione ai libri storici della Bibbia ebraica. Appunti ad uso degli studenti», PIB (Roma 2000-2001) 83-86, que hemos sintetizado y vertido al castellano con ciertas variaciones y complementos. Aún más sucinto se puede encontrar también en IBíD., 
hay bastante debate respecto de esos indicios tanto en particular, como en general ${ }^{23}$. Ahora bien, siempre siguiendo al profesor Rofé, pasaremos revista a algunos elementos textuales que indican que el relato de Gn 24 es tardío:

- Uso de apelativos divinos típicamente tardíos como «el Señor Dios del cielo» (v. 7) o «el Señor Dios del cielo y de la tierra» (v. 3). Estos apelativos se encuentran en libros bíblicos recientes, como Esdras y Nehemías $^{24}$, y en documentos hebreos/arameos extrabíblicos de época persa como los famosos papiros provenientes de la colonia militar hebrea de la isla de Elefantina en el alto Egipto (siglo $\mathrm{V}$ a. C.).

- En Gn 24, 21. 38. 41.49 no se usa la construcción adversativa clásica kî 'im, «sino que», sino la más reciente construcción 'im-lō', «si no», tal como en la Misná y en el hebreo posterior (se dice 'ello ${ }^{2}$ que deriva de la contracción de $\hat{\imath}+10^{2}$ ).

- En Gn 24, 15, a un verbo en perfecto (qatal) sigue la partícula térem, «antes de», tal como se reporta en no pocos manuscritos hebreos de

La composizione del Pentateuco (Bologna 1999) 99-100 = Jerusalem 1994 (en hebreo moderno).

23 Por ejemplo, G.J. Wenham, Genesis 16-50, 139 reconoce que son «innegables» las similitudes lingüísticas que A. Rofé señala entre Gn 24, por una parte, y textos tardíos del AT y relatos rabínicos, por otra, pero al mismo tiempo les resta todo valor pues parte del principio contrario al que está detrás del razonamiento del exegeta jerosolimitano, esto es, es más fácil suponer que escribas posteriores (Esd, Ne, etc.) usaron una terminología antigua y evocaron viejas costumbres, que sostener que estas ideas fueron inventadas en el postexilio. A mi juicio, esta afirmación adolece de una petición de principios: ¿qué seguridad hay que la terminología de Gn 24 o las costumbres que relata sean antiguas? G.J. WenhAm trata de demostrarlo recurriendo al análisis de F. García López, «Del "Yahwista” al "Deuteronomista”: Estudio Crítico de Gn 24», $R B$ (1980) 242-273. 350-393. 514-559 que establece afinidades lingüísticas con textos reconocidamente yavistas, que juzga antiguos (entre el siglo IX y VII a. C.) y ciertas expansiones de vocabulario E o D y añadidos posteriores de la escuela deuteronomista. Es evidente, el juicio de ambos autores depende de una teoría que hoy solo pocos se empecinan en defender contra la evidencia que demuestra que los estratos más antiguos del Pentateuco - preexílicos- eran fragmentarios. Cf. J.-L. SKA, «Los materiales preexílicos del Pentateuco» en IBíD, Introducción, 275-293.

24 Cf., p. ej., 2Cr 36, 23; Esd 1, 2; 5, 1-12; 6, 9-10; 7, 12. 21. 23; Ne 1, 4-5; 2, 4. 20; Dn 2, 18-19. 37. 44; 5, 23. Expresiones similares se encuentran también en los libros deuterocanónicos griegos Tobías y Judit. 
Qumrán, mientras que en el hebreo clásico dicha partícula es siempre seguida por un verbo en imperfecto (wayiqtol) ${ }^{25}$.

El contenido de Gn 24 también revela que el texto es bastante reciente:

- Llama la atención la ausencia del mōharar ${ }^{26}$, es decir, el precio que en las tratativas de un matrimonio el novio o su familia pagan al padre de la novia por el traspaso de la autoridad de la mujer; muy probablemente era una práctica legal obligatoria en el preexilio ${ }^{27}$. Hay evidencia histórica que prueba que, en el período del Segundo Templo, el mōḥar fue tomando otra fisonomía, llegando a equiparárselo con utensilios de valor que el novio o su familia daban a la novia en la celebración del matrimonio y que en caso de divorcio, ella se llevaba consigo al volver a su casa paterna. Así lo atestiguan algunos papiros de la colonia militar hebrea de Elefantina (siglo V a. C.). Finalmente, importantes escritos rabínicos posteriores reportan un ulterior estadio de desarrollo del mōḥar en tiempos aún más recientes, su transformación en una promesa del novio en la celebración del matrimonio por la cual se compromete a pagar una cierta cantidad a la mujer en caso de divorciarse de ella en el futuro ${ }^{28}$.

Por tanto, la ausencia de mōharo en las tratativas entre el siervo de Abrahán y la familia de Rebeca revela el altamente probable origen tardío de Gn 24. Además, la misma ausencia se detecta en el libro de Tobías, aunque no así en Gn 29-30, lo que sirve de indicio para postular que tal vez este último relato sea de origen preexílico.

- Las promesas divinas aludidas en Gn 24 son juradas o sancionadas con un pacto, así como lo son en el libro del Deuteronomio, escrito reconocidamente tardío. Pese a que este argumento es bastante débil, pues supone que las promesas simplemente pronunciadas corresponden a los estratos más antiguos de las tradiciones contenidas en el Pentateuco; es evidente que es el juramento lo que en Gn 24 sirve de base para ulteriores desarrollos: envío de un ángel protector (vv. 7.40); asistencia e iluminación divina en el encargo recibido (vv. 12-15.42); guía divina

25 Cf. Gn 2, 5; 19, 4; Ex 9, 30; 12, 34; Nm 11, 33; etc.

26 En este argumento nos distanciamos del profesor Rofé y seguimos más de cerca la fuente que él cita: J. Collins, «Marriage, Divorce and Family in Second Temple Judaism» en L.G. Perdue y otros. Families in Ancient Israel (Louisville 1997) 113-115.

27 Cf. Ex 22, 16-17; cf. también 1Sam 18, 25; 1Re 9, 5.

28 Cf. b. Ketub 82b, citado y explicado en J. Collins, «Marriage», 113-115. 
por el camino (vv. 21.27). Estos corresponden a motivos típicamente tardíos, abundantes en la literatura intertestamentaria hebrea bíblica y apócrifa. Baste mencionar, por ejemplo, el uso de estos motivos en los libros de Daniel y Tobías ${ }^{29}$.

- La función de la oración en Gn 24 también delata su origen postexílico. De hecho, se repite tres veces un mismo esquema, a saber: a) antes de que suceda lo que desea Abrahán o su siervo, ellos oran; b) lo pedido se realiza; c) después de acaecido, el orante agradece al Señor. Percibimos el esquema desarrollado junto al pozo (vv. 11-26); en la narración que el siervo hace a la familia de Rebeca (vv. 42-48); y en el momento del consentimiento al enlace de la familia de la joven (v. 52).

Si bien es cierto que el tema de la oración en el Antiguo Testamento es complejo, se puede señalar que el esquema recién descrito, oraciónacontecimiento-agradecimiento, constatado tres veces en $\mathrm{Gn} 24$, es característico de la literatura hebrea del período del Segundo Templo, toda vez que es congruente con la vivencia de la fe de los hebreos de la diáspora, que no pueden acudir a Jerusalén para realizar los sacrificios de acción de gracias, prescritos en el Levítico y otros cuerpos legales de la Torá. En ese contexto histórico, la oración asume el rol de acto de culto posible, a la mano de todos, tanto que, con el tiempo, llega a estructurarse la costumbre de orar en acción de gracias tres veces al día, tal como lo hace Daniel en la lejanía de Jerusalén (Dn 6, 10.13). Además el esquema oración-acontecimiento-agradecimiento se encuentra presente en otros textos tardíos de la Biblia como en los libros de Judit y Tobías ${ }^{30}$.

Los argumentos hasta aquí expuestos, siempre siguiendo al profesor Rofé, muestran con claridad que el relato del matrimonio de Isaac con Rebeca es tardío, postexílico. Esta datación hace más fácil iluminar el mundo de los destinatarios de Gn 24, en especial descubrir cuáles eran

\footnotetext{
Cf., por ejemplo, el motivo del ángel protector en Dn 3, 19; 6, 22; Tb 5, 4.13; 6, 19.

30 Cf., por ejemplo, Tobit y Sara oran separadamente al Señor en la desgracia que los aflige ( $\mathrm{Tb} 3,2-6$ y 3, 11-15, respectivamente). Luego se realiza su maravillosa liberación por la intervención de Tobías y con la ayuda de Rafael, el ángel protector ( $\mathrm{Tb}$ 4-10), durante la cual Sara y Tobías suplican al Señor su favor (Tb 8, 5-8). Finalmente, los sanados agradecen al Señor su intervención milagrosa (Tobit en Tb 11, 14-15; Tobías y Sarra en Tb 13).
} 
sus necesidades vitales, o lo que es lo mismo, qué se quería enseñar con esta historia ${ }^{31}$ :

- No dar como esposa a Isaac una mujer cananea corresponde a una dura negación de los matrimonios mixtos. Esta postura se comprende bien a la luz de lo descrito en Esd 8-10 y Ne 13 donde queda de manifiesto el desafío de la comunidad hebrea organizada en torno al Segundo Templo por asegurar su subsistencia nacional en base a una configuración familiar y social que no admitiera sombra alguna de heterodoxia. En efecto, la unión con mujeres cananeas en Gn 24 corresponde, en el rollo de Esdras-Nehemías, a la unión con las hijas de los así tildados «pueblos de la tierra» ${ }^{32}$.

Naturalmente, con esta prohibición se quiere evitar la introducción en la sociedad israelita, por vía femenina, de desviaciones de la ortodoxia religiosa. En la tradición hebrea ya se había reflexionado sobre este peligro. Es más, la también tardía escuela deuteronomista había juzgado precisamente que la tolerancia de los matrimonios mixtos había sido una de las causas principales de la decadencia, degeneración y posterior abandono de la Ley durante la monarquía preexílica. El ejemplo emblemático

31 A. Rofé, Introdurione ai libri storici, 85-86 las puntualiza con toda claridad: «Cosa vuole insegnare questa storia? Un duplice messaggio: 1) non dare in moglie a Isacco una donna tra le figlie dei Cananei; è quindi contrario ai matrimoni misti e questo è comprensibile sullo sfondo di Esd 8-10 e di Ne 13;2) la proibizione con cui Abramo vietava severamente al servo di non fare tornare Isacco nel paese di origine. Anche questo motivo è facilmente comprensibile. Come abbiamo visto nel libro delle $\mathrm{Cr}, \mathrm{i}$ Giudei, dopo la restaurazione temevano fortemente che il loro paese passasse nelle mani di altri popoli (cfr. 2Cr 20: la preghiera di Giosafat). In effetti, la povera e montagnosa Giudea non poteva alimentare gran parte della sua popolazione (specialmente negli anni di siccità) per cui molti abbandonavano la Giudea, attraversavano la pianura, e passavano in Egitto oppure in Siria e poi in Cappadocia e da qui in Asia Minore. A questa situazione si riferisce il divieto di Abramo al servo: "non farai tornare mio figlio colà».

32 Algunos exegetas señalan que los así tildados «pueblos de la tierra» en el rollo de Esd-Ne corresponden a los hebreos que no habían sido exiliados a Babilonia y que permanecieron en Palestina durante el destierro de sus hermanos. En Esd 9, 1 son identificados con una serie de pueblos: cananeos, heteos, amorreos, ferezeos, heveos y jebuseos, los enemigos históricos de Israel, los cuales son enumerados casi idénticamente en no pocos textos del Pentateuco (p. ej., Ex 3, 8.17; 13, $5 \mathrm{Nm} \mathrm{13,} \mathrm{29;} \mathrm{Dt}$ $7,1 ; 20,17)$ y que corresponden a los habitantes de la tierra prometida, que serán desheredados cuando Israel tome posesión de ella. Cf. B. Schramm, The Opponents of Third Isaiah. Reconstructing the Cultic History of the Restoration (Sheffield 1995) 53-64; J.L. SKA, Introducción, 218-219. 
es Salomón quien «desvió su corazón del Señor» a causa de las muchas mujeres paganas que tomó por esposas, quienes lo indujeron a introducir cultos paganos en Jerusalén (cf. 1Re 11,1-11). Pero el matrimonio mixto que se lleva con mucho la mayor repulsión de la escuela deuteronomista es el enlace del rey Ajab y la pérfida Jezabel, hija del rey de Tiro. Esta última es una de las figuras más oscuras de toda la Biblia. Ella, además de introducir cultos paganos en Israel (cf. 1Re 16, 31-34; cf. 1Re 18-19), trajo la perversión social y la inestabilidad política del país (cf. 1Re 21 y $2 \operatorname{Re} 9$ ).

- La prohibición que impone Abrahán a su siervo de no llevar a Isaac al país de donde el patriarca había salido (Gn 24, 5-6) es un motivo que refleja con claridad el ambiente postexílico para el que fue escrito el relato. En efecto, la prohibición deja entrever la desastrosa situación socioeconómica de los habitantes de Jerusalén en el postexilio, como reporta en el rollo de Esd-Ne, sobre todo en Ne 1-2: Nehemías, bajo el impulso divino y con el apoyo y mandato de la autoridad imperial persa, vuelve a Jerusalén para restaurar las murallas y así terminar con la centenaria indefensión de la ciudad. En efecto, desde la destrucción del 587 a. C., la ciudad se hizo muy insegura, lo que provocó un flujo de emigración semiforzada de los judíos no exiliados que incrementó las filas de los hebreos de la diáspora en el decurso de los siglos ${ }^{33}$. Además, este proceso se debe haber visto propulsado también por la pobreza agrícola y ganadera de la comarca jerosolimitana, máxime si, de tanto en tanto, era azotada por la sequía ${ }^{34}$.

Estas dos observaciones nos enfrentan a las tesis que sitúan el origen del Pentateuco en el postexilio, las cuales se alejan cada vez con mayor nitidez y convicción de la hipótesis documental clásica ${ }^{35}$. Estas teorías están

33 La aprensión se detecta también en Gn 26, 2: el Señor ordena que Isaac no descienda de Palestina a pesar de la gran carestía que ese territorio padece producto de la sequía. Muy probablemente, en el postexilio, el autor del relato quiere revertir la emigración de los hebreos que han engrosado las populosas comunidades hebreas de la diáspora.

34 Para una descripción del clima semiárido de Palestina cf., p. ej., J.A. Soggin, Storia d'Israel (Brescia 1984) 27-29.

35 Una descripción detallada de la gestación, desarrollo y declive de hipótesis documental clásica J.-L. SKA, «La exégesis del Pentateuco. Historia de la investigación desde la antigüedad hasta 1970» en IBÍD., Introducción, 135-174 e IBíD., «Los desarrollos recientes en la exégesis del Pentateuco» en IBíD., Introducción, 175-224. 


\section{aún en ciernes y requieren todavía de mucho afinamiento ${ }^{36}$. En efecto,} los especialistas están en búsqueda de algún paradigma que explique la

36 Los estudios diacrónicos tradicionales, en cambio, señalaban una historia de composición de los libros veterotestamentarios que emanaba principalmente de la hipótesis documental, cuya expresión clásica se alcanzó en las obras de Julius Wellhausen a finales del siglo XIX (aquí sintetizamos la descripción del profesor J.-L. SKA cf. nota anterior). Esta hipótesis explica la composición del Pentateuco como una fusión de cuatro documentos independientes, completos y sucesivos: El Yavista (J) habría sido escrito en el sur durante el siglo IX a. C. (apogeo de la monarquía davídico-salomónica); el Elohísta (E), escrito aproximadamente un siglo después, en el reino del Norte e influido por los primeros profetas (siglo VIII a. C.); el Deuteronomio (D), que, en su núcleo más antiguo, se remontaría a la reforma de Josías en el año 622 a. C. y, por último, el Sacerdotal (P), una obra exílica o postexílica vinculada a la empresa de reconstrucción del templo de Jerusalén. El Pentateuco en su forma actual habría sido compuesto, con toda probabilidad, en la época del segundo templo, y muchos relacionan su redacción final con la reforma de Esdras (cf. Ne 8-12). El resto del AT se dató siguiendo los mismos principios. Después de alcanzar la forma clásica no se hicieron sino retoques y matizaciones a la teoría. Ella encontró además escasos detractores, los cuales carecieron de resonancia relevante en el ambiente académico. El esquema de la hipótesis documentaria clásica y su ampliación a todo el Antiguo Testamento, claro está que con matizaciones, disquisiciones o precisiones llevadas casi al infinito en los detalles, fue mantenido casi como un verdadero dogma hasta no hace mucho en los ambientes académicos -y en no pocos centros de estudio sigue hasta hoy vigente-, pero como el monstruo de la mítica visión de Daniel descansaba sobre pies de barro (Dn 2, 33-34) y fácilmente se desplomó. Su debilidad radicaba en que se atañía casi exclusivamente a los datos bíblicos que, además, debía forzar para hacerlos calzar todos en una misma parrilla argumentativa. La arqueología ha demostrado que varios de los presupuestos en que se apoyaba esta teoría eran muy débiles. Así, por ejemplo, los testimonios de cultura material, que las excavaciones en los sitios hebreos de Palestina han arrojado, tienden a negar la posibilidad de la existencia de una edad de oro de la literatura bajo los reinados de David y de Salomón en una supuesta floreciente escribanía de corte. Muy rudimentarios debieron ser los reinados del caudillo de Belén y su hijo, imposible que tuvieran los medios materiales para dedicar el personal necesario a una escribanía que les permitiera tener un desarrollo cultural y literario como el que la hipótesis documental clásica postulaba. De aquella época, a lo más, se podría pretender la existencia de inscripciones rupestres o escritura sobre fragmentos cerámicos (óstraca). Pero las inconsistencias no son solo materiales, sino también en cuanto a las ideas. Por ejemplo, una de las insistencias de la supuesta Historia Sagrada Yavista es la realización de las promesas divinas de la bendición de todas las naciones a través de Israel (Abraham: Gn 12, 1-3). Esta idea parece suponer un desarrollo teológico universalista propio de los profetas de época exílica como Jeremías (Jr 4, 2) y el segundo Isaías (Is 56, 1-8). Por estas razones, desde 1970 hasta ahora la hipótesis documental clásica se ha ido desmoronando, salvándose solo algunos de sus elementos, aquellos cuya prueba está fundada en datos controlables. Los dos más significativos son los siguientes: 1) la datación exílica del Deuteronomio y su vinculación con el libro del profeta Jeremías; 2) la datación 
composición del Pentateuco y, en general, la formación del Antiguo Testamento. Se impone, eso sí, una constatación: Israel puso por escrito solo aquellas tradiciones que daban sentido a su existencia en una época donde esto no solo fue materialmente posible, sino también necesario para su subsistencia como nación. Materialmente fue posible escribir los grandes segmentos del Pentateuco solo en la época del apogeo de los reinos hebreos (hacia el siglo VIII y VII a. C.) ${ }^{37}$. Probablemente, de esta época provengan los materiales más antiguos. Con todo, parece más seguro que el grueso de la composición de las distintas tradiciones narrativas, legales, proféticas y sapienciales contenidas en el Pentateuco y en el resto de la Biblia Hebrea haya acaecido en época exílica y postexílica. En primer lugar, porque se puede demostrar que en esa época las condiciones materiales del pueblo lo permitieron con mayor facilidad. Piénsese, por ejemplo, en las cartas en arameo y en hebreo pertenecientes a la colonia militar hebrea de Elefantina en el Alto Nilo (actual Aswan), datadas precisamente en el período de la dominación persa (siglos V y IV a. C.) y que testimonian el intercambio epistolar entre dicha colonia y las autoridades de Jerusalén de aquella época ${ }^{38}$. En segundo término, porque Israel necesitaba conservar su identidad ante la pérdida de su territorio y de la monarquía, institución que lo había cohesionado antes del colapso de Jerusalén en año el 587 a. C. Esta necesidad vital ciertamente está detrás de la redacción del Pentateuco y de la obra de no pocos profetas y otros escritos de la Biblia Hebrea. Esto no significa, sin embargo, que en su composición no se hayan usado importantes materiales preexílicos ${ }^{39}$.

Por otra parte, la forma final del Pentateuco y, en general, del Antiguo Testamento está vinculada con toda seguridad a la crisis cultural y religiosa que la paulatina y sostenida helenización produjo en el pueblo elegido.

exílica y/o postexílica de los textos sacerdotales, incluido el libro del Levítico, y su vinculación con el libro del profeta Ezequiel.

37 Cf. J.-L. SKA, Introducción, 238-239. Vale la pena estudiar las fuentes extrabíblicas que nos hablan del inicio del desarrollo cultural y político del reino de Israel en el siglo IX a. C., como la estela de Meshá que da cuenta del poderío de Omrí y su dinastía; cf. A. Dearman, Studies in the Mesha Inscription and Moab (Atlanta 1989); IBíD., «Mesha Stela» en D.N. Freedman, Anchor Bible Dictionary (Doubleday 1992) 4708-4709.

38 Cf. J.M. Lindenberger, Ancient Aramaic and Hebrew Letters (Atlanta 1994); B. Porter, The Elephantine Papyri in English. Three Milennia of Cross-Cultural Continuity and Change (Leiden 1996).

39 P. ej., para los elementos preexílicos del Pentateuco cf. J.-L. SKA, «Los materiales preexílicos del Pentateuco» en IBíD, Introducción, 275-293. 
En efecto, una forma de vida adecuada al helenismo lentamente se fue imponiendo al pueblo hebreo creyente tanto en Palestina, como en la diáspora, especialmente bajo la dominación de los imperios helenísticos (333-63 a. C.), sobre todo, bajo el reinado seléucida (198-63 a. C.). Este movimiento cultural y político suscitó la reacción nacionalista y religiosa de importantes segmentos de la población hebrea en Palestina que concluyó con la revuelta de los Macabeos, según se reporta en el primer libro de los Macabeos (datado hacia el año 100 a. C.), cuyos relatos y fuentes son rastreables también en las obras de Flavio Josefo ${ }^{40}$.

Con lo dicho hasta aquí, podría quedar la impresión que se está postulando una exégesis del Antiguo Testamento de corte exclusivamente histórica y radicada en preocupaciones preponderantemente sociológicas y políticas. ¿Dónde queda la teología?, ¿corresponde solo a las ideologías que sustentan los diversos proyectos históricos de los grupos sobrevivientes a la hecatombe de la destrucción de los reinos hebreos en los siglos VII y VI a. C., a saber, la teología deuteronomista de los ancianos, la teología sacerdotal de los aaronitas, sadoquitas y levitas, y la teología sintética de las dos corrientes teológicas anteriores expresadas en la Ley de la Santidad ( $\operatorname{lv} 17-26) ?^{41}$, ¿deben ellas entenderse como parte de la superestructura que explica performativamente la infraestructura que hemos llamado subsistencia de Israel en el postexilio?

Ciertamente, estas interrogantes extrapolan los términos del argumento. La exégesis diacrónica actual en sus mejores expresiones no reduce la teología de los textos a ideas fuerza, ya sustentadoras y/o constructivas de un orden sociopolítico, ya subversivas del orden establecido. Con todo, un reduccionismo de este cuño es siempre una amenaza que debe tenerse presente. Pero tampoco debe negarse la dimensión social y política de las ideas contenidas en los escritos del Pentateuco (y en general en toda la Biblia).

La teología del Pentateuco (y de todo el Antiguo Testamento) es histórica, en términos más precisos, es histórico-salvífica. No se la puede aislar -desnaturalizar- de la historia del pueblo creyente, que, debatiéndose «entre el temor y la esperanza», toma conciencia de la elección divina precisamente en la gesta histórica de su constitución y sobrevivencia

40 Cf. 1Mac 16, 23-24 y la nota de la Biblia de Jerusalén al v. 24.

41 Cf. J.-L. SKA, «Puntos firmes para la interpretación: tres códigos; tres teologías; la última redacción» en IBíD, Introducción, 255-260, espec. 258-260. 
como pueblo ${ }^{42}$. Esta asunción de su elección se cristalizó especialmente en la hora crucial del postexilio. En ese preciso período, las viejas tradiciones históricas fueron leídas y reelaboradas por los ancianos y sacerdotes en clave de pervivencia del pueblo como nación: Israel puede seguir existiendo, pese a que no posee en la actualidad ni territorio ni soberano propios -los dos elementos constitutivos de todo pueblo medioriental en la antigüedad- pues en su origen no los poseía. De hecho, cuando comenzó a existir como pueblo peregrinaba por el desierto, mucho antes de recibir y tomar en posesión la tierra prometida. En aquella época remota Israel tampoco tenía monarca, su rey era solo el Señor $(E x$ 15, 18), cuyo pacto había transformado a los israelitas de un conglomerado de esclavos prófugos, en pueblo de su propiedad:

3«Moisés subió al encuentro de Dios y el Señor lo llamó desde la montaña: Así dirás a la casa de Jacob y anunciarás a los israelitas. ${ }^{4} \mathrm{Han}$ visto lo que hice a los egipcios y cómo los puse a ustedes sobre alas de águila y los traje a mí. ${ }^{5}$ Ahora, si realmente desean obedecerme, guardarán mi alianza y serán mi especial posesión entre los pueblos, pues toda la tierra es mía; 'serán para mí un reino de sacerdotes y una nación santa. Estas son las palabras que debes decir a los israelitas» (Ex 19, 3-6).

La teología del Pentateuco -o la sinfonía de teologías que se dan cita en él- no está desvinculada de la historia, pues la historia es el escenario donde Dios se ha revelado a Israel e Israel así lo ha percibido. Pero, al mismo tiempo, el proyecto histórico del Israel postexílico se trasciende a sí mismo, pues sus gestores comprenden que en la génesis del pueblo entra en juego un actor sobrenatural, el Señor, que tiene un designio de plenitud humana y social que va más allá de los estrechos cálculos de los que fraguan los destinos de los pueblos. Esto era válido para ese entonces y continúa siéndolo hasta ahora.

Algo parecido sostenía G. von Rad ${ }^{43}$. Comparando Enuma Elish, célebre mito cosmogónico babilónico, y el relato bíblico de los orígenes, el exégeta de München hacía notar que el primero termina con la fundación

42 Cf. A. MeIs, «III. Formas histórico-salvíficas de la autocomunicación de Dios» en IBÍD., Antropología Teológica. Acercamientos a la paradoja del hombre (Santiago 1997) 154158, donde resulta sugerente la presentación que la autora hace de las distintas fases en que Israel va tomando conciencia de que «debe su existencia a la autocomunicación de Dios».

43 Cf. G. von RAD, «Palabra de Dios e historia en el Antiguo Testamento» en IBíD., La acción de Dios en Israel, 173-195. 
de Babilonia, la capital de un imperio y, por lo mismo, se autorrevela en el fondo como una explicación justificante de un poder temporal. El segundo, en cambio, desemboca en una explicación que se extiende al destino universal de la humanidad, pues finaliza en la así llamada tabla de las naciones ( $\mathrm{Gn}$ 10). En ella, Israel no entiende su destino desvinculado del resto de los pueblos. La particularización de la historia de los orígenes solo adviene con las narraciones referidas a Abrahán, pero tampoco ellas resultan ser una restricción de la dispensación del favor divino, sino, por el contrario, la puesta en marcha con más decisión de un designio de salvación que incumbirá a todos pueblos ${ }^{44}$.

Hace algunos años leí el fantástico libro titulado «Oltre la Bibbia» de M. Liverani ${ }^{45}$, en cuyo prefacio sintetiza magníficamente el sentido en que el Pentateuco y en general todo el Antiguo Testamento es histórico. Lo es no en cuanto «historia normal», sino en cuanto «historia inventada» de Israel.

Según el autor, la «historia normal» de Israel no se encuentra en la Biblia, pues el relato de la sucesión de acontecimientos de aquellos dos reinos hebreos del área de Palestina en el bronce tardío, Israel y Judá, no son rastreables en las páginas de las Sagradas Escrituras hebreas de modo confiable desde el punto de vista de la ciencia histórica. Esto no quiere decir que para la relación histórica el Antiguo Testamento no aporte datos importantes, sino que ellos son limitados toda vez que mientras más se retrocede en el tiempo se vuelven siempre más inseguros. Además, la historia normal de Israel y Judá solo importa a los especialistas, que tal vez podrían disponer de otros ejemplos incluso mejor documentados entre los otros reinos que compartieron el escenario palestino en aquella época lejana: Karkemish, Tiro o Gaza. Todos sujetos a la destrucción,

44 J.-L. SKA, Introducción, 166-167, especialmente la nota 92 señala que en Gn 12, 3: «Bendeciré a quienes te bendigan y maldeciré a quienes te maldigan. Por ti se bendecirán todos los linajes de la tierra», algunos autores, siguiendo a G. von Rad, interpretan este pasaje como la expresión del destino universal de la salvación y la particular misión de Israel en ese destino. Con todo, siempre siguiendo al exegeta belga, esta interpretación no se condice con el sentido literal del texto, que debe interpretarse como una invocación o alabanza que todas las naciones harán respecto de la fidelidad de Abrahán. Pese a esta interesante clarificación, no se puede obviar que la misión de Israel en relación a la salvación de la humanidad entera está fundada en varios textos del Antiguo Testamento (cf. Is 66, 18-24; Rut; Jonás, Ml 1, 11, etc.) y es asumida por el NT (cf., p. ej., Mt 8, 11; Mt 24, 31; Hch 3, 21, etc.). 
deportación y desculturación en manos de los imperios hegemónicos que se sucedieron: Asiria primero y Babilonia después.

La historia inventada de Israel, siempre siguiendo a Liverani, se encuentra en la Biblia y es el relato histórico que el pueblo judío antiguo ha hecho de sus orígenes para sustentar su existencia como nación. Una historia que tiene que ver con la explicación de la tragedia nacional provocada por la destrucción de Jerusalén y, con ella, la promesa divina sobre la que descansaba el ideal patrio y religioso del reino de Judá fundado (o refundado) por el rey Josías (cf. 2Sam 7, 6-18) y su pretensión de albergar bajo su dominio a «todo Israel» (Dt 1, 1 cf. Gn 15, 18; Dt 1, 7; 11, 24; etc.). Una historia que tiene que ver con la esperanza eminentemente postexílica de basar la existencia de una nación, Israel, en las instituciones que lograron sobrevivir o revivieron después de la hecatombe: el templo reconstruido y la Ley (cuyas raíces naturalmente son preexílicas). Esta historia es inventada en el sentido de que ha sido encontrada como fundamento de aquel presente que los análisis histórico-críticos logran poner a la luz con mayor o menor precisión.

La historia inventada por el Israel exílico y postexílico interesa no solo a los especialistas, sino también a un amplio número de estudiosos e, incluso al gran público, pues está a la base de la fundación del judaísmo, religión que ha «influido en el curso completo de la historia sucesiva a escala mundial $»^{46}$. Interesa particularmente a la teología cristiana en cuanto que le permite darse cuenta cómo la comunidad creyente, de la que la Iglesia se siente heredera y continuadora, ha percibido a Dios actuando y manifestando su poder y misericordia en las vicisitudes de su existencia nacional como pueblo elegido, pero no como destinatario exclusivo y excluyente de la bendición o favor divino, como era lo acostumbrado en las religiones del mundo medioriental antiguo, sino como instrumento de salvación de todas las generaciones (Gn 12,1-3; cf. Is 66, 18-24).

¡Y vaya paradoja! Israel solo capta esta misión cuando precisamente experimenta su propia debilidad y ve amenazada su subsistencia como pueblo por la destrucción de su Santuario, la pérdida de la libertad y del propio territorio, y la imposición del duro exilio. Por eso, el desierto es el escenario del origen de Israel como nación: fuera de la tierra prometida y sin tener rey propio. Lo que asegura la existencia del pueblo elegido, por tanto, es la alianza con el Señor -el verdadero rey de Israel-, que no solo

46 M. Liverani, Oltre la Bibbia, IX. 
elige a los hebreos, sino que también les enseña el camino, la Torá, para alcanzar la plena realización personal y comunitaria aún sin entrar jamás en la tierra.

Resumen: Teología e historia en el Antiguo Testamento están íntimamente compenetradas, pues los relatos bíblicos nos ponen en contacto con el mundo de sus destinatarios y, en especial, con sus necesidades vitales, a las que un autor concreto intentaba dar respuesta. El artículo ejemplifica esta realidad comunicativa en Gn 24. Así pone de manifiesto que la teología del Antiguo Testamento, y particularmente la del Pentateuco, es histórico-salvífica, esto es, narra la autoconciencia de Israel de su elección divina precisamente en la gesta histórica de su constitución y sobrevivencia como pueblo, especialmente en la hora crucial del postexilio. En efecto, la historia es el escenario donde Dios se ha revelado a Israel e Israel así lo ha percibido. Pero, al mismo tiempo, el proyecto histórico del Israel postexílico se trasciende a sí mismo, pues el Señor tiene un designio de plenitud humana y social que va más allá de los estrechos cálculos de los que fraguaron el destino del pueblo en aquella época remota. Por eso, la teología plasmada en los libros de la Biblia sigue siendo válida en el presente, principalmente porque delata que el Señor continúa actuando en la historia.

Palabras clave: Historia, teología, Antiguo Testamento, Pentateuco, postexilio, hagiógrafo.

Abstract: Theology and history in the Old Testament are intimately blended. Biblical stories bring us into contact with the world of their recipients, and especially with their vital needs, to which a particular author attempts to provide a solution. This article exemplifies this communicative reality in Gn 24. It thus shows that the theology of the Old Testament, and particularly that of the Pentateuch, is historical-salvific, that is, it tells of Israel's self-awareness of its divine election precisely in the historic feat of its establishment and survival as a people, especially during the crucial time of post-exile. Effectively, history is the stage where God revealed Himself to Israel and Israel so perceived it. However, at the same time, post-exilic Israel's historical project transcends itself, because the Lord has a plan of social and human fulfillment that surpasses the narrow calculations of those who forged the destiny of the people in that remote age. Thus, the theology embodied in the books of the Bible continues to be valid today, mainly because it portrays that the Lord continues to act in history.

Keywords: history, theology, Old Testament, Pentateuch, post-exile, hagiographer 